\title{
Financial Literacy, Financial Education, and Smoking Behavior: Evidence From Japan
}

\author{
Somtip Watanapongvanich, Mostafa Saidur Rahim Khan, Pongpat Putthinun, \\ Shunsuke Ono and Yoshihiko Kadoya* \\ School of Economics, Hiroshima University, Hiroshima, Japan
}

\section{OPEN ACCESS}

Edited by:

Hideki Hashimoto,

The University of Tokyo, Japan

Reviewed by:

Salvador Cruz Rambaud, University of Almeria, Spain

Rei Goto,

Keio University, Japan

*Correspondence:

Yoshihiko Kadoya

ykadoya@hiroshima-u.ac.jp

Specialty section:

This article was submitted to

Health Economics,

a section of the journa

Frontiers in Public Health

Received: 01 October 2020 Accepted: 08 December 2020

Published: 15 January 2021

Citation:

Watanapongvanich S, Khan MSR, Putthinun $P$, Ono $S$ and Kadoya $Y$ (2021) Financial Literacy, Financial

Education, and Smoking Behavior:

Evidence From Japan

Front. Public Health 8:612976.

doi: 10.3389/fpubh.2020.612976
In this study, we examine the relationship between financial literacy, financial education, and smoking behavior among the Japanese population. We hypothesize that financially literate and financially educated people, who have the ability to make more rational decisions, are less likely to smoke. Using the Preference Parameters Study of Osaka University, conducted in 2010 ( $N=3,706)$, the probit regression results show that both financial literacy (with an emphasis on knowledge of investments) and financial education (with an emphasis on savings behavior) have a significant negative impact on smoking behavior. In addition, gender, age, education, marital status, household income and assets, risky behaviors, a myopic view of the future, risk preference, and level of happiness also significantly predict the likelihood of a person being a current smoker. This study provides empirical evidence that enhancing the rational decision-making ability of individuals through financial literacy and financial education may curtail smoking behavior.

Keywords: smoking, financial literacy, financial education, Japan, healthcare decision

\section{INTRODUCTION}

Smoking has become an increasing public health concern in Japan over the past several decades. In 2012, the Japanese government set a target to reduce the smoking rate among adults aged 20 and over to $12 \%$ by 2022 (1). Since then, government and non-government organizations have taken several actions to curtail smoking, such as prohibiting indoor smoking, increasing the tobacco tax, and providing smoking cessation services (2). However, the prevalence of smoking in Japan has remained unchanged since 2013 (3-5). According to the Global Burden of Disease Study (GBD), Japan had the world's seventh-largest population of smokers in 2015 (6), and the 2017-2019 WHO report on the global tobacco epidemic indicates that $19 \%$ of Japanese aged 15 and over, $\sim 21$ million people, still smoke $(4,5)$. These statistics raise the question of why smoking is still relatively prevalent in the country despite continued efforts to curtail it. It also seems likely that the government will not reach its smoking reduction target in the near future.

Smoking has substantially negative health [e.g., (7-13)], behavioral [e.g., (14-16)], and economic consequences [e.g., $(17,18)]$. One important question is why do many people still engage in smoking despite its harmful effects. Smoking, as an addictive behavior, could be explained from three competing theoretical frameworks: rational, imperfect rational, and irrational choice $(19,20)$. Becker and Murphy (21) advanced the rational choice theory and postulated that smoking is a rational choice made on the basis of utility maximizing criteria. This means that people, by using available information, find that present pleasure of smoking provides more utility than the utility loss from its adverse consequences. However, the rational choice theory has been challenged 
on the ground that smokers do not have all the relevant information at the time when they make smoking decisions, and they cannot objectively assess the value of information. We support the argument that smoking decisions are not rational, but rather either imperfectly rational or completely irrational.

Imperfectly rational framework postulates that smokers show bounded rationality because of their poor judgment over future health effects and time-inconsistent preferences. Compared with rational decision makers' time consistency over discounting immediate present and distant future outcomes, imperfectly rational smokers tend to be hyperbolic in discounting future consequences over current pleasure from smoking. Barlow et al. (22), MacKillop et al. (23), Ida and Goto (24), Baker et al. (21), and Mitchell (25) argued that smoking is associated with a high discount rate, meaning that smokers greatly discounted the future compared with the present outcomes. Barlow et al. (22) reviewed 69 relevant studies and argued that higher discounting was the reason for decisions to smoke and reluctance to quit even though smokers know future health consequences. O'Donoghue and Rabin (26) and Gruber and Köszegi (27) considered timeinconsistent people as biased toward the present. In other words, smokers value the pleasure they receive from smoking in the present whilst heavily discounting the negative consequences of smoking in the future (20). Besides hyperbolic discounting, several studies modeled time-inconsistent addictive behavior by the exponentiated hyperbolic discounting (28) and subadditive discounting $(29,30)$. In addition to time-inconsistency, smokers, particularly young smokers, are often found to have imperfect information; they lack judgment in understanding future health consequences and sometimes become addicted suddenly (3135). The human capital model developed by Grossman (36) confirmed that smokers tend to place less emphasis on human capital as they heavily discount future health effects. Grossman (36) found that smoking destroys health capital, thereby decreasing human capital and ultimately taking a toll on productivity. Moreover, smokers often fail to recognize that the adverse effects of smoking not only affect them directly but also result in higher social costs from negative externalities and health care burdens $(17,37)$ compared with the social benefits of socially desirable outcomes (17). Cognitive limitation could be a possible reason why imperfectly rational people are unable to properly value the health consequences of smoking.

Finally, the conceptual framework that conjectures smoking as an irrational behavior postulates that decisions to smoke are guided by emotions, which hinder objective assessment of risks and benefits associated with the consumption. When emotions drive decisions, people lose their rationality and deviate from the objective assessment of information. Decision to smoke as an addictive good is sometimes triggered by external causes leading to impulsive behavior $(20,38)$. Moreover, Perikleous et al. (39) confirmed the evidence of peer influence on adolescent smoking, which confirmed that smokers do not always make unbiased decisions.

How to reduce people's tendency to smoke has been an area of great concern over the decades. One approach to prevent people from making imperfectly rational or irrational decisions is to enable them to make rational decisions. In this study, we propose that financial literacy is a rational decision-making instrument, as the people who possess this knowledge tend to behave more rationally; this is reflected in their economic and financial behavior (40-50). Moreover, financial literacy is related to improved cognitive ability $(51,52)$, which helps them become time-consistent in making judgment over current and future outcomes. Because of rational decision-making ability and increased cognitive ability, financially literate people are likely to make informed decision, place due importance on future outcomes, be time-consistent, and not be influenced by emotions. Thus, financially literate people, being rational agents, are less likely to be smokers because of their ability to objectively assess the benefits and health risks of smoking. In support of the ability to make rational decisions, previous studies provided evidence that financially literate people are engaged in better healthcare decision-making and health-promoting activities (53, 54). Because of the relevance of financial literacy with positive health behavior, better health outcomes, and quality of life in later years, positive reinforcement should be solicited in the society. Similar to financial literacy, financial education received in school is likely to make people aware of financial issues and help them to make informed and rational decisions (55-58).

Although previous studies show that financial literacy is associated with better health-related decision-making, few empirical studies have investigated the relationship between financial literacy and health behaviors. A recent study by Watanapongvanich et al. (59) used financial literacy and financial education to explain gambling behavior among the Japanese population. They found that financial literacy has a significantly negative relationship with gambling frequency, whilst financial education has an insignificant impact. Existing research also shows that the thought processes behind smoking and gambling have the same intertemporal relationship with the financial decision-making process $(21,25,60,61)$ and that gambling and smoking are proxies for irrational behaviors that can lead to negative consequences. Therefore, apart from gambling, it is worth investigating how financial literacy and financial education can reduce smoking behavior in Japan.

In this study, we examine the relationship between financial literacy, financial education, and smoking behavior. We hypothesize that financially literate and financially educated people, who have the ability to make more rational decisions, are less likely to be smokers. To the best of our knowledge, no existing empirical research addresses the association between financial literacy, financial education, and smoking behavior. Our study contributes to the existing literature by providing empirical evidence on the connection between financial literacy and financial education as a rational decision-making tool and how they affect irrational decisions tied to smoking behavior in Japan. The results of this study can help policymakers implement effective interventions to prevent and minimize the negative consequences of smoking.

The remainder of this paper is organized as follows. In sections Data and Methodology, the data and methodology are described, respectively. In section Results, the empirical results are summarized, in section Robustness Check, robustness of the 
results are checked, and in section Discussion, the results are discussed. Section Conclusion presents the conclusion.

\section{DATA}

\section{Data}

In this study, we use data from the Preference Parameters Study (PPS) conducted by the Institute of Social and Economic Research at Osaka University. The PPS is a panel survey that collects information on socioeconomic characteristics and preferences from a representative sample of the Japanese population. In this study, we utilized data from the 2010 wave, which contained questions about smoking behavior, financial literacy, and financial education. The sample includes data from 3,706 individuals, or $\sim 69 \%$ of all respondents in $2010(5,386$ individuals). We excluded individuals with missing data on smoking behavior, financial literacy, financial education, and demographic variables (1,680 individuals).

\section{Variable Definitions}

The dependent variable in this study is smoking behavior. The PPS contains the question "Do you smoke?" and provides seven responses, where 1 means "do not smoke at all," 2 means "hardly smoke," 3 means "smoke sometimes," 4 means "about 10 cigarettes a day," 5 means "about a pack a day," 6 means "more than two packs a day," and 7 means "I used to smoke but have quit." We grouped these responses into a binary scale of non-smokers and current smokers by coding respondents who answered 1,2 , or 7 as 0 or non-smokers (62) and those who answered 3, 4, 5, or 6 as 1 or current smokers.

There are two main variables of interest in our study: financial literacy and financial education. To measure financial literacy, we followed the methodology proposed by Lusardi and Mitchell (63), which is simple and widely adopted in existing literature [e.g., (59, 64-71)]. It uses the following three questions.

a. Suppose you had 10,000 JPY in a savings account and the interest rate is $2 \%$ per year and you never withdraw money or interest payments. After 5 years, how much would you have in this account in total?

- More than 10,200 JPY (correct answer)

- Exactly 10,200 JPY

- Less than 10,200 JPY

- Do not know

- Refuse to answer

b. Imagine that the interest rate on your savings account was $1 \%$ per year and inflation was $2 \%$ per year. After 1 year, how much would you be able to buy with the money in this account?

- More than today

- Exactly the same

- Less than today (correct answer)

- Do not know

- Refuse to answer

c. Please indicate whether the following statement is true or false. "Buying a company stock usually provides a safer return than a stock mutual fund."
- True

- False (correct answer)

- Do not know

- Refuse to answer

The first two questions measure the respondent's understanding of how compound interest works and the effect of inflation. Indeed, the questions help evaluate a respondent's understanding of economic concepts and basic numeracy (63). The third question evaluates respondents' understanding of the concept of risk diversification. In this study, we assigned a score of one for each correct answer and 0 for each incorrect answer. We obtained the financial literacy variable by taking the equally weighted average scores of the three questions.

For financial education, the respondents were asked, "Did you receive any compulsory financial education when you were in elementary school?" with three possible responses: yes, no, and do not know. We coded the respondents who answered yes as one and those who answered no or do not know as 0 . We treated this as a binary variable.

We should note an important difference between financial literacy and financial education in Japan. A recent work by Watanapongvanich et al. (59) suggests that Lusardi and Mitchell's (63) financial literacy questions measure respondents' current level of financial knowledge from an investment perspective. However, the Japanese school curriculum includes financial education to teach students about savings using a children's bank campaign $(59,72)$. Therefore, financial literacy that focuses on investment concepts is somewhat different from financial education that focuses on savings behavior (59). Sekita (71), who found that receiving financial education through a children's bank campaign has no effect on the level of financial literacy among representative Japanese adults, also supports this claim. Consequently, we include both financial literacy and financial education as explanatory variables in this study.

Furthermore, we include gender, age, university degree, marital status, household members, employment status, household income, and household assets as demographic variables in our specifications. We also control for risky behaviors (exercise, drinking alcohol, and gambling behavior), myopic view of the future, risk preference, level of happiness, and anxiety about health. Table 1 provides the definitions of all the variables.

\section{Descriptive Statistics}

The descriptive statistics in Table 2 show that $24.26 \%$ of respondents were current smokers. On average, respondents' financial literacy scores were 0.59 and $15.33 \%$ of the sample received financial education at school. For the demographic variables, about $49.24 \%$ of the sample were men and the average age was 49.79 years. Approximately $27.06 \%$ of the sample hold a university degree, $82.25 \%$ of the sample were currently married, and $3.45 \%$ were divorced. The respondents had four household members on average, and about $84.43 \%$ of the sample had children. Only $2.40 \%$ of the sample were currently unemployed. Respondents had an annual household income of $\sim 6.49$ million JPY on average and 13.10 million JPY in household assets in 
TABLE 1 | Variable definitions

\begin{tabular}{|c|c|}
\hline Variables & Definitions \\
\hline Smoking behavior & $\begin{array}{l}\text { Binary variable: } 1=\text { current smoker (sometimes-more than } \\
\text { two packs a day) and } 0=\text { non-smokers (do not smoke at all, } \\
\text { quit, or hardly smoke) }\end{array}$ \\
\hline Financial literacy & $\begin{array}{l}\text { Continuous variable: number of correct answers from three } \\
\text { financial literacy questions }\end{array}$ \\
\hline $\begin{array}{l}\text { Financial } \\
\text { education }\end{array}$ & $\begin{array}{l}\text { Binary variable: } 1=\text { received compulsory financial education } \\
\text { at school and } 0=\text { otherwise }\end{array}$ \\
\hline Male & Binary variable: $1=$ male and $0=$ female \\
\hline Age & Respondent's age \\
\hline Age squared & Age squared \\
\hline University degree & $\begin{array}{l}\text { Binary variable: } 1=\text { obtained university degree and } 0= \\
\text { otherwise }\end{array}$ \\
\hline Marriage & Binary variable: $1=$ married and $0=$ otherwise \\
\hline Divorce & Binary variable: $1=$ divorced or separated and $0=$ otherwise \\
\hline $\begin{array}{l}\text { Household } \\
\text { members }\end{array}$ & $\begin{array}{l}\text { Continuous variable: number of people currently living in } \\
\text { household }\end{array}$ \\
\hline Children & Binary variable: $1=$ have child/children and $0=$ otherwise \\
\hline Unemployed & $\begin{array}{l}\text { Binary variable: } 1=\text { respondent is unemployed and } 0= \\
\text { otherwise }\end{array}$ \\
\hline Household income & $\begin{array}{l}\text { Continuous variable: annual earned income before taxes and } \\
\text { with bonuses of the entire household in } 2009 \text { (unit: JPY) }\end{array}$ \\
\hline $\begin{array}{l}\text { Log of household } \\
\text { income }\end{array}$ & Log (household income) \\
\hline Household assets & $\begin{array}{l}\text { Continuous variable: balance of financial assets (savings, } \\
\text { stock, insurance, etc.) of the entire household (unit: JPY) }\end{array}$ \\
\hline $\begin{array}{l}\text { Log of household } \\
\text { assets }\end{array}$ & Log (household assets) \\
\hline Regular exercise & $\begin{array}{l}\text { Binary variable: } 1=\text { regular exercise (exercise once a week or } \\
\text { more) and } 0=\text { otherwise }\end{array}$ \\
\hline Current drinker & $\begin{array}{l}\text { Binary variable: } 1=\text { current drinker (drink sometimes-five } \\
\text { cans of beer daily) and } 0=\text { otherwise }\end{array}$ \\
\hline Frequent gambler & $\begin{array}{l}\text { Binary variable: } 1=\text { frequent gambler (gamble once a week } \\
\text { or more) and } 0=\text { otherwise }\end{array}$ \\
\hline $\begin{array}{l}\text { Myopic view of the } \\
\text { future }\end{array}$ & $\begin{array}{l}\text { Binary variable: } 1=\text { agree and completely agree with the } \\
\text { statement "Since the future is uncertain, it is a waste to think } \\
\text { about it" and } 0=\text { otherwise }\end{array}$ \\
\hline $\begin{array}{l}\text { Level of risk } \\
\text { preference }\end{array}$ & $\begin{array}{l}\text { Continuous variable: percentage score from the question } \\
\text { "Usually, when you go outdoors, how high does the } \\
\text { probability of rain have to be before you take an umbrella?" }\end{array}$ \\
\hline $\begin{array}{l}\text { Current level of } \\
\text { happiness }\end{array}$ & $\begin{array}{l}\text { Continuous variable: percentage score from the question } \\
\text { "Overall, how happy would you say you are currently?" }\end{array}$ \\
\hline $\begin{array}{l}\text { Anxiety about } \\
\text { health }\end{array}$ & $\begin{array}{l}\text { Binary variable: } 1 \text { = agree and completely agree with the } \\
\text { statement "I have anxieties about my health" and } 0= \\
\text { otherwise }\end{array}$ \\
\hline
\end{tabular}

2009. For risky behaviors, $37.13 \%$ of the participants exercised regularly, whilst $54.16 \%$ were current drinkers and $9.42 \%$ were frequent gamblers. Overall, $14.54 \%$ of the respondents had a myopic view of the future and risk preferences of $49.08 \%$; in other words, they were risk neutral. Respondents rated their current level of happiness at $64.72 \%$, and $41.99 \%$ of the sample were anxious about their health.
TABLE 2 | Descriptive statistics.

\begin{tabular}{|c|c|c|c|c|}
\hline Variables & Mean & $\begin{array}{l}\text { Standard } \\
\text { deviation } \\
\text { (SD) }\end{array}$ & Min & Max \\
\hline Smoking behavior & 0.2426 & 0.4287 & 0 & 1 \\
\hline Financial literacy & 0.5914 & 0.3436 & 0 & 1 \\
\hline Financial education & 0.1533 & 0.3603 & 0 & 1 \\
\hline Male & 0.4924 & 0.5000 & 0 & 1 \\
\hline Age & 49.79 & 12.61 & 20 & 76 \\
\hline Age squared & 2637.63 & 1239.67 & 400 & 5,776 \\
\hline University degree & 0.2706 & 0.4444 & 0 & 1 \\
\hline Marriage & 0.8225 & 0.3822 & 0 & 1 \\
\hline Divorce & 0.0345 & 0.1826 & 0 & 1 \\
\hline Household members & 3.52 & 1.44 & 1 & 10 \\
\hline Children & 0.8443 & 0.3626 & 0 & 1 \\
\hline Unemployed & 0.0240 & 0.1531 & 0 & 1 \\
\hline Household income & $6,486,239$ & $3,777,635$ & $1,000,000$ & $20,000,000$ \\
\hline Log of household income & 15.51 & 0.61 & 13.82 & 16.81 \\
\hline Household assets & $13,100,000$ & $17,600,000$ & $2,500,000$ & $100,000,000$ \\
\hline Log of household assets & 15.81 & 1.01 & 14.73 & 18.42 \\
\hline Regular exercise & 0.3713 & 0.4832 & 0 & 1 \\
\hline Current drinker & 0.5416 & 0.4983 & 0 & 1 \\
\hline Frequent gambler & 0.0942 & 0.2921 & 0 & 1 \\
\hline Myopic view of the future & 0.1454 & 0.3526 & 0 & 1 \\
\hline Level of risk preference & 0.4908 & 0.1891 & 0 & 1 \\
\hline Current level of happiness & 0.6472 & 0.1822 & 0 & 1 \\
\hline Anxiety about health & 0.4199 & 0.4936 & 0 & 1 \\
\hline
\end{tabular}

Observations

3,706

Tables 3-5 present the distribution of smoking behavior classified by age group, demographic characteristics, and risky behaviors, respectively. Our sample contained 899 current smokers; that is, $24.26 \%$ of the total sample smoke between sometimes to more than two packs of cigarettes daily, whilst the remaining 2,807 respondents were non-smokers. The results in Table 3 indicate significant differences in smoking behavior among age groups. The proportion of current smokers in the oldest age group (age 61 and older) was 17.27\%, which is less than other age groups that the proportions of current smokers are more than 22\%. In Table 4, we see significant differences in smoking behavior between genders. Approximately $37.15 \%$ of male respondents were current smokers compared to $11.75 \%$ of female respondents. However, the differences in smoking behavior by education level and employment status are insignificant. The results in Table 5 for risky behaviors show that about $19.11 \%$ of respondents who exercise regularly are current smokers, which is less than the sample of current smokers who do not exercise regularly (27.30\%). In addition, we see considerable differences in smoking behavior between current drinkers and non-drinkers and between frequent gamblers and non-gamblers. 
TABLE 3 | Distribution of smoking behavior by age group.

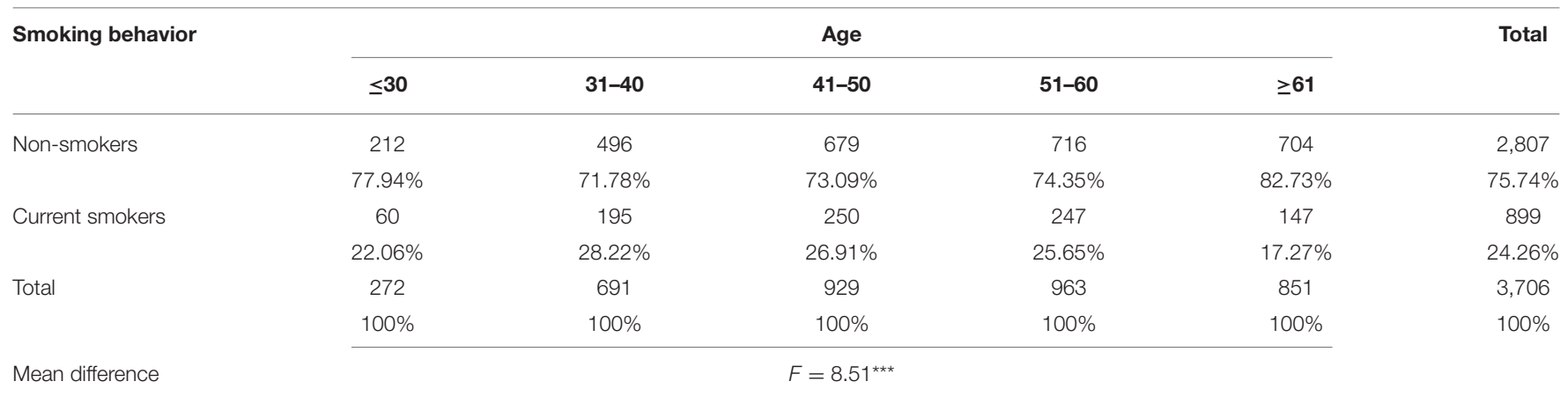

${ }^{\star \star *} p<0.01,{ }^{\star \star} p<0.05,{ }^{\star} p<0.10$.

TABLE 4 | Distribution of smoking behavior by demographic characteristic.

\begin{tabular}{|c|c|c|c|c|c|c|c|}
\hline Smoking behavior & \multicolumn{2}{|c|}{ Gender } & \multicolumn{2}{|c|}{ Education } & \multicolumn{2}{|c|}{ Unemployed } & Total \\
\hline \multirow[t]{2}{*}{ Non-smokers } & 1,660 & 1,147 & 2,035 & 772 & 2,743 & 64 & 2,807 \\
\hline & $88.25 \%$ & $62.85 \%$ & $75.29 \%$ & $76.97 \%$ & $75.84 \%$ & $71.91 \%$ & $75.74 \%$ \\
\hline \multirow[t]{2}{*}{ Total } & 1,881 & 1,825 & 2,703 & 1,003 & 3,617 & 89 & 3,706 \\
\hline & $100 \%$ & $100 \%$ & $100 \%$ & $100 \%$ & $100 \%$ & $100 \%$ & $100 \%$ \\
\hline Mean difference & \multicolumn{2}{|c|}{$t=-18.8786^{\star \star \star}$} & \multicolumn{2}{|c|}{$t=1.0614$} & \multicolumn{2}{|c|}{$t=-0.8535$} & \\
\hline
\end{tabular}

${ }^{\star \star *} p<0.01,{ }^{\star \star} p<0.05,{ }^{\star} p<0.10$.

TABLE 5 | Distribution of smoking behavior by risky behaviors.

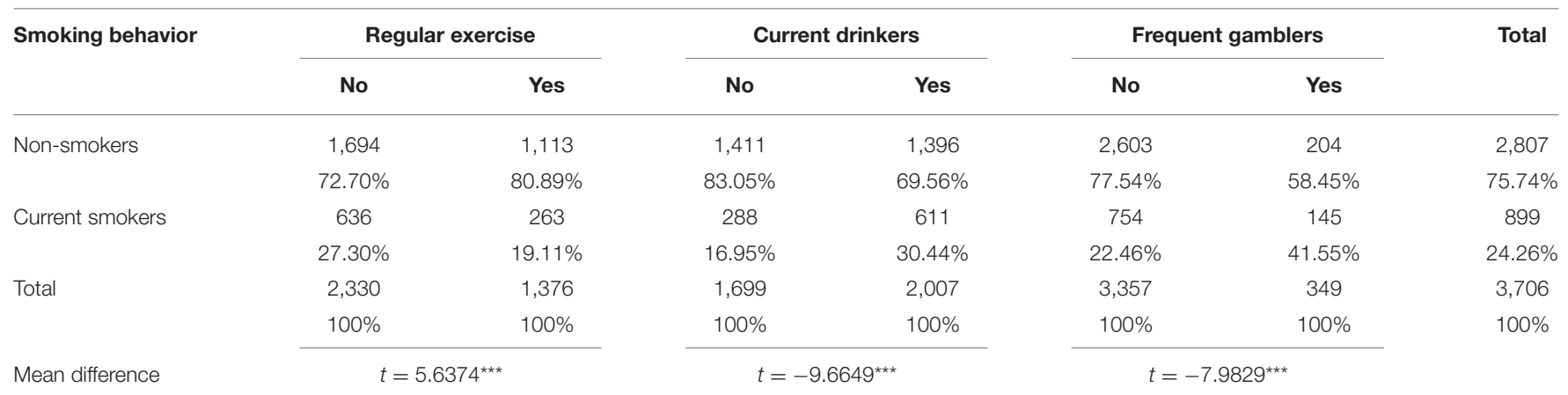

${ }^{\star \star *} p<0.01,{ }^{\star \star} p<0.05,{ }^{*} p<0.10$

Specifically, $30.44 \%$ of current drinkers and $41.55 \%$ of frequent gamblers were current smokers.

\section{METHODOLOGY}

To investigate how financial literacy and financial education are related to smoking behavior, we first separately estimate the effects of financial literacy and financial education in Equations $(1,2)$, respectively. We then include both financial literacy and financial education to see the combined effect of the variables in Equation (3).

$$
\begin{array}{r}
Y_{i}=f\left(F L_{i}, X_{i}, \varepsilon_{i}\right) \\
Y_{i}=f\left(F E_{i}, X_{i}, \varepsilon_{i}\right) \\
Y_{i}=f\left(F L_{i}, F E_{i}, X_{i}, \varepsilon_{i}\right)
\end{array}
$$

where $\mathrm{Y}_{\mathrm{i}}$ is the smoking behavior of the $i$ th respondent (current smokers or non-smokers), FL represents the score on the 
financial questions measuring financial literacy, FE represents financial education received at school, $\mathrm{X}$ is a vector of individual characteristics, and $\varepsilon$ is the error term. Because the dependent variable is a binary choice, we employ a probit regression to estimate all equations.

As there is a potential for multicollinearity between the explanatory variables in the models (i.e., individuals with a high level of education could have high financial knowledge, or individuals with high net worth may have more financial knowledge because of experience with asset management), we conducted correlation and multicollinearity tests in all models (available upon request). The results show that multicollinearity between the variables is not significant, suggesting that the independent effects of explanatory variables on smoking behavior are not biased. The correlation matrix shows a weak relationship between the explanatory variables (lower than 0.70 ). In addition, the variance inflation factor (VIF) tests of the explanatory variables are below 10, indicating that multicollinearity is not significant in all models.

The full model specifications are

Smoking behavior $_{i}(1=$ current smokers and $0=$ non - smokers $)$

$=\beta_{0}+\beta_{1}$ financial literacy $_{i}+\beta_{2}$ male $_{i}+\beta_{3}$ age $_{i}+$ $\beta_{4}$ age squared $_{i}+\beta_{5}$ university degree $_{i}+\beta_{6}$ marriage $_{i}+\beta_{7}$ divorce $_{i}+$ $\beta_{8}$ household members $_{i}+\beta_{9}$ children $_{i}+\beta_{10}$ unemployed $_{i}+\beta_{11} \log$ of household income ${ }_{i}+\beta_{12}$ logofhousehold assets $_{i}+$ $\beta_{13}$ regular exercise $_{i}+\beta_{14}$ current drinkers $_{i}+\beta_{15}$ frequent gamblers $_{i}$ $+\beta_{16}$ myopic view of the future ${ }_{i}+\beta_{17}$ level of risk preference ${ }_{i}+$ $\beta_{18}$ current level of happiness $i+\beta_{19}$ anxiety about health ${ }_{i}+\varepsilon_{i}$ (1a) Smoking behavior $_{i}(1=$ current smokers and $0=$ non - smokers $)$

$=\beta_{0}+\beta_{1}$ financial education $_{i}+\beta_{2}$ male $_{i}+\beta_{3}$ age $_{i}+$ $\beta_{4}$ age squared $_{i}+\beta_{5}$ university degree $_{i}+\beta_{6}$ marriage $_{i}+\beta_{7}$ divorce $_{i}+$ $\beta_{8}$ household members $_{i}+\beta_{9}$ children $_{i}+\beta_{10}$ unemployed $_{i}+\beta_{11} \log$ of household income $_{i}+\beta_{12}$ logofhousehold assets $_{i}+$ $\beta_{13}{\text { regular } \text { exercise }_{i}+\beta_{14} \text { current }_{\text {drinkers }}+}_{+}+$ $\beta_{15}$ frequent gamblers $_{i}+\beta_{16}$ myopic view of the future ${ }_{i}+\beta_{17}$ level of risk preference $_{i}+\beta_{18}$ current level of happiness $_{i}+$ $\beta_{19}$ anxiety about health ${ }_{i}+\varepsilon_{\mathbf{i}}$

Smoking behavior $_{i}(1=$ current smokers and $0=$ non - smokers $)$ $=\beta_{0}+\beta_{1}$ financial literacy $_{i}+\beta_{2}$ financial education $_{i}+$ $\beta_{3}$ male $_{i}+\beta_{4}$ age $_{i}+\beta_{5}$ age squared $_{i}+$ $\beta_{6}$ university $_{\text {degree }_{i}}+\beta_{7}$ marriage $_{i}+\beta_{8}$ divorce $_{i}+$ $\beta_{9}$ household members $_{i}+\beta_{10}$ children $_{i}+\beta_{11}$ unemployed $_{i}+\beta_{12} \log$ of household income $_{i}+\beta_{13}$ logofhousehold assets $_{i}+$ $\beta_{14}$ regular exercise $_{i}+\beta_{15}$ current $_{\text {drinkers }}+$ $\beta_{16}$ frequent gamblers $_{i}+\beta_{17}$ myopic view of the future ${ }_{i}+\beta_{18}$ level of risk preference $_{i}+\beta_{19}$ current level of happiness $_{i}+$ $\beta_{20}$ anxiety about health ${ }_{i}+\varepsilon_{\mathbf{i}}$

\section{RESULTS}

We present the results of the probit regression to estimate Equations (1)-(3) in Tables 6-8, respectively. Each table presents the results of four different specifications of the explanatory variables. The first specification (Models 1.1, 2.1, and 3.1) included controls for only the demographic variables. In the second specification (Models 1.2, 2.2, and 3.2), we added risky behaviors including exercise, drinking alcohol, and gambling. The third specification (Models 1.3, 2.3, and 3.3) included respondents' myopic views of the future and risk preferences. Finally, the fourth specification (Models 1.4, 2.4, and 3.4) included respondents' self-rated level of happiness and anxiety about health.

The results in Table 6 show that financial literacy has a negative and strongly significant impact on smoking behavior across the models. In Table 7, we see that financial education also has a negative and significant impact on smoking behavior in all models except Model 2.2. However, the significance levels of the financial education variables (at 5 and 10\%) are less than those of the financial literacy variables (at \% and 5\%). Since both financial literacy and financial education have a significant impact on smoking behavior, we regress financial literacy on financial education and the other control variables to explore the relationship between these two variables. We find that financial literacy and financial education are not correlated (results not reported here, but available upon request), consistent with the finding of Sekita (71). Therefore, we should use both financial literacy and financial education as explanatory variables in the same equation to explain smoking behavior, as shown in our final model in Table 8.

The results in Table 8 show that, overall, there are no differences in the significance of the estimated parameters compared to the results in Tables 6, 7. The coefficients of our variables of interest, financial literacy, and financial education are negative and statistically significant in all models except financial education in Model 3.2. In other words, respondents with a high level of financial literacy and those who received financial education were less likely to be current smokers at present.

For the demographic and other control variables, most of the signs and significance levels of the coefficients are consistent across models and specifications. Male, age, and divorce have a positive impact on being a current smoker, and the coefficients are strongly significant at the $1 \%$ level. In contrast, age squared, university degree, log of household income, and log of household assets have a negative and significant impact on being a current smoker. However, marriage, household members, children, and employment status have an insignificant impact. In terms of risky behaviors, regular exercise has a negative impact, whilst being a current drinker and frequent gambler have a positive impact on current smoking status, statistically significant at the $1 \%$ level. Furthermore, a myopic view of the future and a high level of risk preference are associated with being current smokers. Conversely, respondents with self-rated high levels of happiness are less likely to be current smokers. However, respondents' anxiety regarding health showed an insignificant impact on smoking behavior.

\section{ROBUSTNESS CHECK}

To check robustness of our results, we used an alternative classification of smoking behavior. Rather than classifying respondents as non-smokers and smokers, we classified them 
TABLE 6 | Probit model regression results, financial literacy as the main explanatory variable.

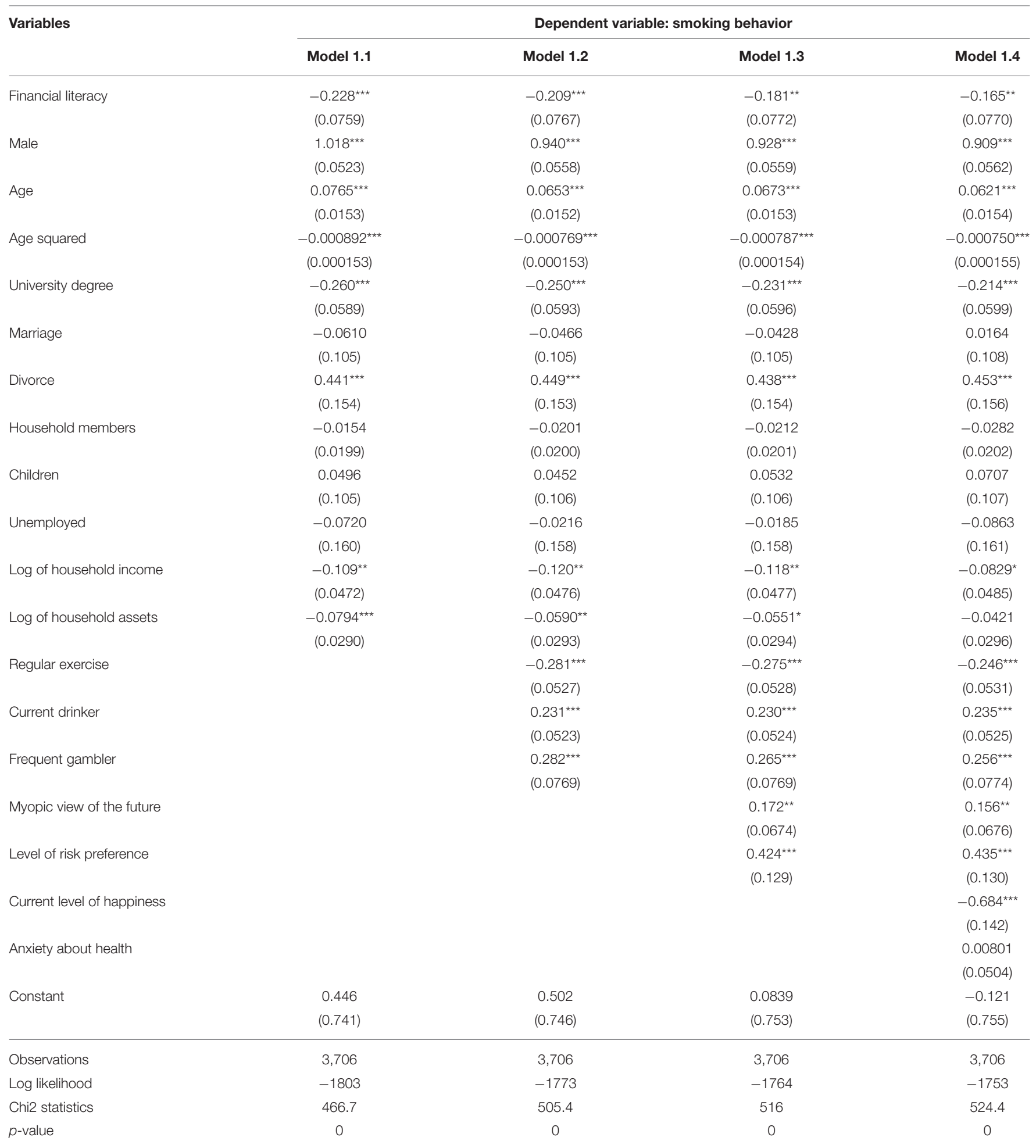

Robust standard errors in parentheses, ${ }^{\star \star *} p<0.01,{ }^{* *} p<0.05,{ }^{*} p<0.1$.

as non-smokers, occasional or intermittent smokers, and regular smokers. The alternative classification allowed us to check rationality in smoking behavior elaborately. Non-smokers included respondents who answered "do not smoke at all" and "I used to smoke but had quit." Occasional smokers included respondents who answered "hardly smoke" and 
TABLE 7 | Probit model regression results, financial education as the main explanatory variable.

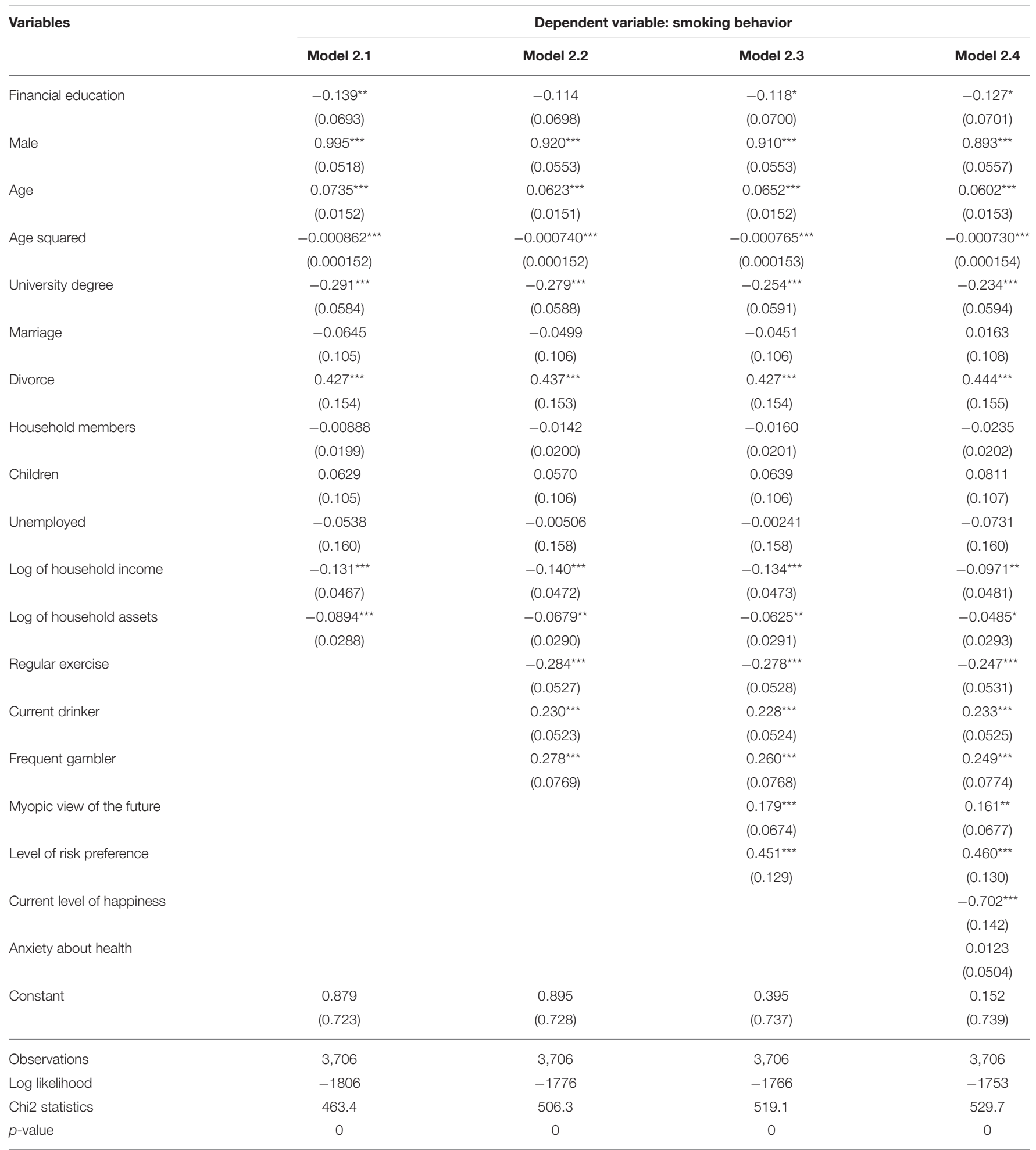

Robust standard errors in parentheses, ${ }^{* \star *} p<0.01,{ }^{* \star} p<0.05,{ }^{*} p<0.1$.

"smoke sometimes." Regular smokers included respondents who answered "about 10 cigarettes a day," "about a pack a day," and "more than two packs a day." Similar to our original models, we hypothesize that respondents who are financially literate or received more financial education are less likely to be regular smokers. 
TABLE 8 | Probit model regression results, financial literacy, and financial education as the main explanatory variables.

\begin{tabular}{|c|c|c|c|c|}
\hline Variables & \multicolumn{4}{|c|}{ Dependent variable: smoking behavior } \\
\hline Financial literacy & $(0.0760)$ & $(0.0768)$ & $(0.0772)$ & $(0.0771)$ \\
\hline \multirow[t]{2}{*}{ Financial education } & $-0.138^{\star \star}$ & -0.113 & $-0.116^{\star}$ & $-0.125^{\star}$ \\
\hline & $(0.0692)$ & $(0.0698)$ & (0.0699) & $(0.0700)$ \\
\hline \multirow[t]{2}{*}{ Age } & $0.0774^{\star \star \star}$ & $0.0661^{\star \star \star}$ & $0.0683^{\star \star \star}$ & $0.0631^{\star \star \star}$ \\
\hline & $(0.0153)$ & $(0.0153)$ & $(0.0153)$ & $(0.0154)$ \\
\hline \multirow[t]{2}{*}{ Age squared } & $-0.000896^{\star \star \star}$ & $-0.000773^{\star \star \star}$ & $-0.000792^{\star \star \star}$ & $-0.000755^{\star \star \star}$ \\
\hline & $(0.000153)$ & $(0.000153)$ & $(0.000154)$ & $(0.000155)$ \\
\hline University degree & $-0.259^{\star \star \star}$ & $-0.250^{\star \star \star}$ & $-0.231^{\star \star \star}$ & $-0.214^{\star \star \star}$ \\
\hline \multirow[t]{2}{*}{ Divorce } & $0.439^{\star \star \star}$ & $0.448^{\star \star \star}$ & $0.437^{\star \star \star}$ & $0.452^{\star \star \star}$ \\
\hline & $(0.154)$ & $(0.153)$ & $(0.154)$ & $(0.155)$ \\
\hline \multirow[t]{2}{*}{ Household members } & -0.0140 & -0.0188 & -0.0199 & -0.0269 \\
\hline & (0.0199) & $(0.0201)$ & $(0.0201)$ & $(0.0202)$ \\
\hline \multirow[t]{2}{*}{ Children } & 0.0503 & 0.0460 & 0.0538 & 0.0716 \\
\hline & $(0.105)$ & $(0.106)$ & $(0.106)$ & $(0.107)$ \\
\hline \multirow[t]{2}{*}{ Unemployed } & -0.0668 & -0.0174 & -0.0134 & -0.0816 \\
\hline & $(0.159)$ & $(0.157)$ & $(0.158)$ & $(0.161)$ \\
\hline \multirow[t]{2}{*}{ Log of household income } & $-0.111^{\star \star}$ & $-0.121^{\star \star}$ & $-0.119^{\star \star}$ & $-0.0837^{\star}$ \\
\hline & $(0.0472)$ & $(0.0476)$ & $(0.0476)$ & $(0.0484)$ \\
\hline Frequent gambler & & $(0.0769)$ & $(0.0769)$ & $(0.0774)$ \\
\hline \multirow[t]{2}{*}{ Myopic view of the future } & & & $0.169^{\star \star}$ & $0.152^{\star \star}$ \\
\hline & & & $(0.0676)$ & $(0.0678)$ \\
\hline \multirow[t]{2}{*}{ Level of risk preference } & & & $0.433^{\star \star \star}$ & $0.444^{\star \star \star}$ \\
\hline & & & $(0.129)$ & $(0.130)$ \\
\hline \multirow[t]{2}{*}{ Current level of happiness } & & & & $-0.689^{\star \star \star}$ \\
\hline & & & & $(0.142)$ \\
\hline \multirow[t]{2}{*}{ Anxiety about health } & & & & 0.0105 \\
\hline & & & & $(0.0505)$ \\
\hline \multirow[t]{2}{*}{ Constant } & 0.438 & 0.492 & 0.0665 & -0.142 \\
\hline & $(0.741)$ & $(0.746)$ & $(0.753)$ & $(0.755)$ \\
\hline Observations & 3,706 & 3,706 & 3,706 & 3,706 \\
\hline Log likelihood & -1801 & -1772 & -1763 & -1751 \\
\hline Chi2 statistics & 471.4 & 510.4 & 522.3 & 531.9 \\
\hline$p$-value & 0 & 0 & 0 & 0 \\
\hline
\end{tabular}

Robust standard errors in parentheses, ${ }^{\star \star *} p<0.01,{ }^{* *} p<0.05,{ }^{*} p<0.1$. 
We used multinomial probit model (mprobit) to investigate how financial literacy and financial education are related to smoking behavior. The results of mprobit regressions are presented in Tables 9-11. Each table presents the results of four different specifications of the explanatory variables where the base model is non-smokers' category. The results in Table 9 show that financial literacy has a negative and significant impact on smoking behavior in all models except Model 4.7 in case of occasional smokers. The results in Table $\mathbf{1 0}$ indicate that financial education also has a negative and significant impact on smoking behavior in regular smokers' category. We included both financial literacy and financial education as explanatory variables in our final model. The results in Table 11 show that, overall, there are no differences in the significance of the estimated parameters compared with the results in Tables 9, 10. The coefficients of our variables of interest, financial literacy and financial education, are negative and statistically significant across models in case of the regular smokers. In other words, compared with non-smokers, respondents with a high level of financial literacy and those who received financial education are less likely to be regular smokers. These results are similar to the probit estimation when smoking behavior is classified into the non-smokers and smokers categories.

\section{DISCUSSION}

As mentioned earlier, there is an important difference between financial literacy and financial education in the Japanese context. Financial literacy measures respondents' current level of financial knowledge and focuses on the investment perspective, whilst financial education focuses on the savings behavior. Our results demonstrate that both financial literacy and financial education have a significant impact on smoking behavior. Hence, the focus of our discussion here is the final model, as shown in Table 8.

Among Models 3.1-3.4, both financial literacy and financial education have a significantly negative impact on smoking behavior, except financial education in Model 3.2. These inverse relationships indicate that respondents with a high level of financial literacy and those who received financial education were less likely to be current smokers. The findings support our hypothesis that financially literate and financially educated people, who have the ability to make more rational decisions, are less likely to make the irrational decision to smoke. Watanapongvanich et al. (59) also found an inverse relationship between financial literacy (as a proxy for a rational decisionmaking tool) and gambling behavior (as a proxy for irrational decisions).

For the demographic variables, we find that being male, older (until a certain age), divorced, and having an education level below university degree, low household income, and low household assets are related to the current smoking status. Our results are consistent with those of previous studies, which found that smoking is more prevalent and progressive in males [e.g., $(13,73-78)$ ] and persons in lower socioeconomic status (SES) [e.g., (73, 79-85)]. A plausible explanation is that persons in higher SES groups tend to have more knowledge about health risks and better access to health care resources and smoking cessation services $(79,84)$, which results in a lower rate of smoking prevalence compared to those in the lower SES group. In addition, persons with lower education levels may suffer from lower selfesteem compared to those who complete higher education and may be more likely to take up smoking as a selfenhancement mechanism (86). Regarding marital status, Lindström (87) and Pennanen et al. (81) found that smokers living without a spouse have higher daily smoking rates and nicotine dependence. Castrén et al. (88) explain that the dissolution of a marriage may cause people to undertake harmful activities.

For risky behaviors, respondents who exercise regularly are less likely to be current smokers, whilst respondents who are current drinkers and frequent gamblers are more likely to be current smokers. Prior studies also report a negative relationship between physical activity and smoking [e.g., (74, 89-91)]. We can predict these results because people who exercise regularly tend to be health conscious and avoid behaviors that cause health deterioration. In contrast, people who are already engaged in health-risk behaviors such as drinking alcohol and gambling tend to engage in other risky behaviors, including smoking. For example, Nichter et al. (92) argue that alcohol makes drinkers more comfortable with the experience of smoking and raises their smoking limit. Therefore, drinkers are more likely to smoke than non-drinkers [e.g., $(93,94)]$. In addition, engaging in gambling also encourages smoking, especially during the game [e.g., (95-97)].

Our results related to a myopic view of the future and level of risk preference, which have a positive impact on smoking behavior, also support our findings on health-risk behaviors. Respondents who have a myopic view of the future will focus more on the present; in other words, they value the pleasant feelings from smoking today more than the adverse effects that smoking will have on their health in the future [e.g., $(24,25,98)]$. Furthermore, respondents with high levels of risk preference tend to engage in risky behaviors more than those with a low level of risk preference [e.g., $(24,99,100)]$. Therefore, respondents with a myopic view of the future and a high level of risk preference are more likely to be current smokers. Lastly, respondents who reported high self-rated levels of happiness are less likely to be current smokers. This finding is consistent with that of Chang et al. (101), who found that in Japan, France, and the UK, if people feel happier, they smoke less. As smoking gives smokers pleasure, they feel more relaxed and energetic; therefore, they use smoking as a coping mechanism to combat stress (101103).

\section{CONCLUSION}

In this study, we examined the relationship between financial literacy, financial education, and smoking behavior among the Japanese population. We hypothesized that financially literate and financially educated people who have the ability 
TABLE 9 | Multinomial probit model regression results, financial literacy as the main explanatory variable.

\begin{tabular}{|c|c|c|c|c|c|c|c|c|}
\hline \multirow[t]{2}{*}{ Variables } & $\begin{array}{l}\text { Occasional } \\
\text { smoker }\end{array}$ & $\begin{array}{l}\text { Regular } \\
\text { smoker }\end{array}$ & $\begin{array}{l}\text { Occasional } \\
\text { smoker }\end{array}$ & $\begin{array}{l}\text { Regular } \\
\text { smoker }\end{array}$ & $\begin{array}{c}\text { Occasional } \\
\text { smoker }\end{array}$ & $\begin{array}{l}\text { Regular } \\
\text { smoker }\end{array}$ & $\begin{array}{c}\text { Occasional } \\
\text { smoker }\end{array}$ & $\begin{array}{l}\text { Regular } \\
\text { smoker }\end{array}$ \\
\hline & Model 4.1 & Model 4.2 & Model 4.3 & Model 4.4 & Model 4.5 & Model 4.6 & Model 4.7 & Model 4.8 \\
\hline \multirow[t]{2}{*}{ Financial literacy } & $-0.269^{\star}$ & $-0.316^{\star \star \star}$ & $-0.257^{\star}$ & $-0.291^{\star \star \star}$ & $-0.243^{\star}$ & $-0.247^{\star \star}$ & -0.234 & $-0.224^{\star \star}$ \\
\hline & $(0.143)$ & $(0.109)$ & (0.142) & $(0.110)$ & $(0.143)$ & (0.110) & $(0.142)$ & $(0.110)$ \\
\hline \multirow[t]{2}{*}{ Male } & $0.643^{\star \star \star}$ & $1.468^{\star \star \star}$ & $0.620^{\star \star \star}$ & $1.355^{\star \star \star}$ & $0.612^{\star \star \star}$ & $1.336^{\star \star \star}$ & $0.594^{\star \star \star}$ & $1.309^{\star \star \star}$ \\
\hline & (0.0979) & $(0.0750)$ & $(0.106)$ & $(0.0797)$ & $(0.106)$ & (0.0798) & $(0.107)$ & (0.0802) \\
\hline \multirow[t]{2}{*}{ Age } & 0.0139 & $0.116^{\star \star \star}$ & 0.0103 & $0.0999^{\star \star \star *}$ & 0.0110 & $0.104^{\star \star \star}$ & 0.00670 & $0.0962^{\star \star \star}$ \\
\hline & (0.0266) & (0.0222) & $(0.0267)$ & (0.0222) & (0.0267) & (0.0222) & (0.0269) & (0.0223) \\
\hline \multirow[t]{2}{*}{ Age squared } & -0.000259 & $-0.00133^{\star \star \star}$ & -0.000218 & $-0.00116^{\star \star *}$ & -0.000230 & $-0.00119^{\star \star \star}$ & -0.000198 & $-0.00114^{\star \star \star}$ \\
\hline & $(0.000271)$ & $(0.000224)$ & $(0.000272)$ & $(0.000224)$ & $(0.000271)$ & $(0.000224)$ & $(0.000272)$ & $(0.000225)$ \\
\hline \multirow[t]{2}{*}{ University degree } & $-0.195^{\star}$ & $-0.396^{\star \star \star}$ & $-0.208^{\star}$ & $-0.382^{\star \star \star}$ & $-0.199^{\star}$ & $-0.351^{\star \star \star}$ & -0.185 & $-0.327^{\star \star \star}$ \\
\hline & $(0.115)$ & (0.0842) & $(0.115)$ & $(0.0847)$ & $(0.115)$ & (0.0852) & $(0.115)$ & $(0.0857)$ \\
\hline \multirow[t]{2}{*}{ Marriage } & 0.0299 & -0.118 & 0.0228 & -0.0954 & 0.0257 & -0.0877 & 0.0736 & -0.00118 \\
\hline & $(0.173)$ & $(0.151)$ & $(0.176)$ & $(0.150)$ & $(0.175)$ & $(0.152)$ & $(0.177)$ & $(0.154)$ \\
\hline \multirow[t]{2}{*}{ Divorce } & $0.482^{*}$ & $0.598^{\star \star \star}$ & $0.465^{\star}$ & $0.612^{\star \star \star}$ & 0.455 & $0.597^{\star \star \star}$ & $0.472^{*}$ & $0.621^{\star \star \star}$ \\
\hline & $(0.280)$ & $(0.220)$ & $(0.280)$ & $(0.219)$ & $(0.280)$ & $(0.220)$ & $(0.280)$ & $(0.221)$ \\
\hline \multirow[t]{2}{*}{ Household member } & 0.0408 & -0.0131 & 0.0365 & -0.0195 & 0.0360 & -0.0219 & 0.0309 & -0.0320 \\
\hline & $(0.0385)$ & (0.0283) & $(0.0384)$ & $(0.0286)$ & $(0.0384)$ & $(0.0286)$ & $(0.0385)$ & $(0.0287)$ \\
\hline \multirow[t]{2}{*}{ Children } & -0.275 & 0.0652 & -0.271 & 0.0562 & -0.262 & 0.0669 & -0.251 & 0.0924 \\
\hline & $(0.175)$ & $(0.151)$ & $(0.176)$ & $(0.151)$ & $(0.176)$ & (0.152) & $(0.177)$ & $(0.153)$ \\
\hline \multirow[t]{2}{*}{ Unemployed } & -0.315 & -0.0875 & -0.303 & -0.0120 & -0.302 & -0.00560 & -0.352 & -0.101 \\
\hline & $(0.331)$ & $(0.230)$ & $(0.332)$ & $(0.228)$ & $(0.333)$ & $(0.229)$ & $(0.339)$ & $(0.232)$ \\
\hline \multirow[t]{2}{*}{ Log of household income } & -0.117 & $-0.140^{\star *}$ & -0.116 & $-0.156^{\star \star}$ & -0.115 & $-0.152^{\star \star}$ & -0.0861 & -0.102 \\
\hline & (0.0928) & $(0.0670)$ & $(0.0931)$ & $(0.0675)$ & (0.0932) & $(0.0676)$ & (0.0939) & $(0.0691)$ \\
\hline \multirow[t]{2}{*}{ Log of household assets } & -0.0541 & $-0.115^{\star \star \star}$ & -0.0456 & $-0.0864^{\star \star}$ & -0.0439 & $-0.0792^{\star}$ & -0.0346 & -0.0609 \\
\hline & $(0.0538)$ & $(0.0413)$ & $(0.0543)$ & $(0.0417)$ & $(0.0546)$ & $(0.0418)$ & $(0.0549)$ & $(0.0420)$ \\
\hline \multirow[t]{2}{*}{ Regular exercise } & & & -0.145 & $-0.386^{\star \star \star}$ & -0.140 & $-0.376^{\star \star \star}$ & -0.120 & $-0.335^{\star \star \star}$ \\
\hline & & & (0.0973) & $(0.0754)$ & $(0.0975)$ & $(0.0756)$ & (0.0980) & $(0.0761)$ \\
\hline \multirow[t]{2}{*}{ Current drinker } & & & 0.162 & $0.329^{\star \star \star}$ & $0.166^{\star}$ & $0.328^{\star \star \star}$ & $0.169^{*}$ & $0.334^{\star \star \star}$ \\
\hline & & & $(0.101)$ & $(0.0748)$ & $(0.100)$ & $(0.0750)$ & $(0.101)$ & $(0.0752)$ \\
\hline \multirow[t]{2}{*}{ Frequent gambler } & & & -0.193 & $0.396^{\star \star \star}$ & -0.197 & $0.368^{\star * *}$ & -0.203 & $0.355^{\star \star \star}$ \\
\hline & & & $(0.175)$ & (0.109) & $(0.175)$ & $(0.110)$ & $(0.175)$ & $(0.110)$ \\
\hline \multirow[t]{2}{*}{ Myopic view of the future } & & & & & $0.211^{\star}$ & $0.254^{\star \star \star}$ & 0.200 & $0.233^{\star \star}$ \\
\hline & & & & & $(0.126)$ & $(0.0967)$ & $(0.126)$ & $(0.0971)$ \\
\hline \multirow[t]{2}{*}{ Level of risk preference } & & & & & 0.0796 & $0.712^{\star \star \star}$ & 0.0883 & $0.726^{\star \star \star}$ \\
\hline & & & & & $(0.248)$ & $(0.185)$ & $(0.248)$ & $(0.186)$ \\
\hline \multirow[t]{2}{*}{ Current level of happiness } & & & & & & & $-0.548^{\star \star}$ & $-0.980^{\star \star \star}$ \\
\hline & & & & & & & $(0.271)$ & $(0.203)$ \\
\hline \multirow[t]{2}{*}{ Anxiety about health } & & & & & & & -0.00979 & -0.00885 \\
\hline & & & & & & & $(0.0955)$ & $(0.0721)$ \\
\hline \multirow[t]{2}{*}{ Constant } & 0.692 & 0.196 & 0.622 & 0.283 & 0.485 & -0.423 & 0.330 & -0.696 \\
\hline & $(1.373)$ & $(1.057)$ & $(1.375)$ & $(1.065)$ & $(1.387)$ & $(1.076)$ & $(1.384)$ & $(1.080)$ \\
\hline Observations & 3,706 & 3,706 & 3,706 & 3,706 & 3,706 & 3,706 & 3,706 & 3,706 \\
\hline Log likelihood & -2433 & -2433 & -2402 & -2402 & -2390 & -2390 & -2378 & -2378 \\
\hline Chi2 statistics & 487.4 & 487.4 & 535.1 & 535.1 & 550.6 & 550.6 & 557.3 & 557.3 \\
\hline p-value & 0 & 0 & 0 & 0 & 0 & 0 & 0 & 0 \\
\hline
\end{tabular}

Robust standard errors in parentheses, ${ }^{\star \star *} p<0.01,{ }^{\star \star} p<0.05,{ }^{\star} p<0.1$. 
TABLE 10 | Multinomial probit model regression results, financial education as the main explanatory variable.

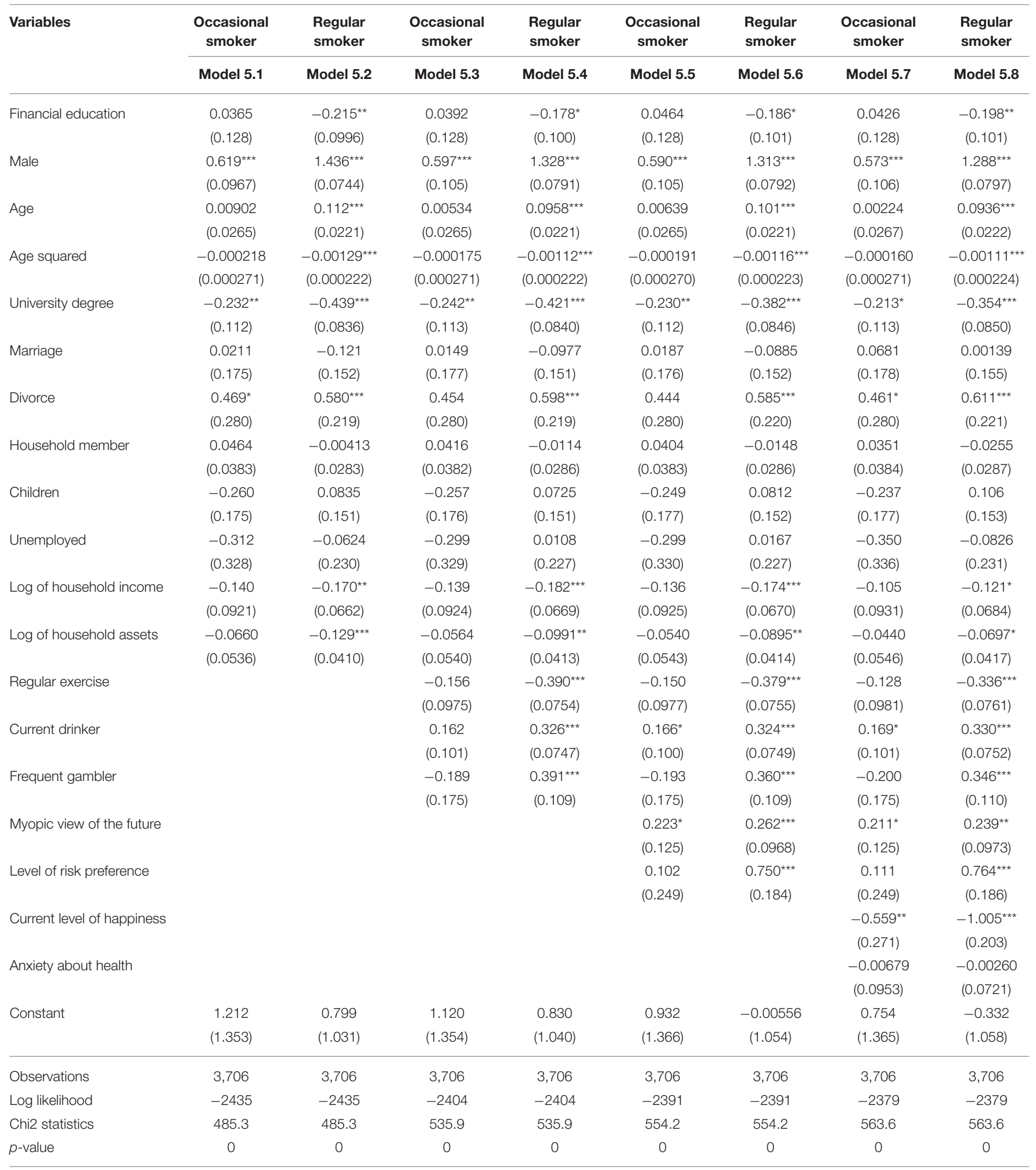

Robust standard errors in parentheses, ${ }^{\star \star *} p<0.01,{ }^{\star \star} p<0.05,{ }^{*} p<0.1$. 
TABLE 11 | Multinomial probit model regression results, financial literacy, and financial education as the main explanatory variables.

\begin{tabular}{|c|c|c|c|c|c|c|c|c|}
\hline \multirow[t]{2}{*}{ Variables } & $\begin{array}{l}\text { Occasional } \\
\text { smoker }\end{array}$ & $\begin{array}{l}\text { Regular } \\
\text { smoker }\end{array}$ & $\begin{array}{l}\text { Occasional } \\
\text { smoker }\end{array}$ & $\begin{array}{l}\text { Regular } \\
\text { smoker }\end{array}$ & $\begin{array}{l}\text { Occasional } \\
\text { smoker }\end{array}$ & $\begin{array}{l}\text { Regular } \\
\text { smoker }\end{array}$ & $\begin{array}{l}\text { Occasional } \\
\text { smoker }\end{array}$ & $\begin{array}{l}\text { Regular } \\
\text { smoker }\end{array}$ \\
\hline & Model 6.1 & Model 6.2 & Model 6.3 & Model 6.4 & Model 6.5 & Model 6.6 & Model 6.7 & Model 6.8 \\
\hline \multirow[t]{2}{*}{ Financial literacy } & $-0.268^{\star}$ & $-0.314^{\star \star \star}$ & $-0.256^{\star}$ & $-0.290^{\star \star \star}$ & $-0.242^{*}$ & $-0.245^{\star \star}$ & -0.233 & $-0.222^{\star \star}$ \\
\hline & $(0.143)$ & (0.109) & $(0.142)$ & $(0.110)$ & $(0.143)$ & $(0.111)$ & $(0.142)$ & $(0.110)$ \\
\hline \multirow[t]{2}{*}{ Financial education } & 0.0386 & $-0.213^{\star \star}$ & 0.0408 & $-0.176^{\star}$ & 0.0480 & $-0.184^{\star}$ & 0.0442 & $-0.196^{\star}$ \\
\hline & $(0.128)$ & (0.0995) & $(0.128)$ & $(0.100)$ & $(0.128)$ & $(0.101)$ & $(0.128)$ & $(0.100)$ \\
\hline \multirow[t]{2}{*}{ Male } & $0.644^{\star \star \star}$ & $1.468^{\star \star \star}$ & $0.621^{\star \star \star}$ & $1.357^{\star \star \star}$ & $0.613^{\star \star \star}$ & $1.337^{\star \star \star}$ & $0.595^{\star \star \star}$ & $1.310^{\star \star \star}$ \\
\hline & (0.0979) & $(0.0750)$ & $(0.106)$ & (0.0796) & $(0.106)$ & $(0.0797)$ & $(0.107)$ & $(0.0802)$ \\
\hline \multirow[t]{2}{*}{ Age } & 0.0138 & $0.118^{\star \star \star}$ & 0.0101 & $0.101^{\star \star *}$ & 0.0107 & $0.105^{\star \star \star}$ & 0.00644 & $0.0977^{\star \star \star}$ \\
\hline & (0.0266) & (0.0223) & $(0.0267)$ & (0.0222) & $(0.0267)$ & $(0.0222)$ & (0.0269) & $(0.0224)$ \\
\hline \multirow[t]{2}{*}{ Age squared } & -0.000260 & $-0.00134^{\star \star \star}$ & -0.000217 & $-0.00116^{\star \star \star}$ & -0.000229 & $-0.00120^{\star \star \star}$ & -0.000197 & $-0.00114^{* \star *}$ \\
\hline & $(0.000271)$ & $(0.000224)$ & $(0.000272)$ & $(0.000224)$ & $(0.000272)$ & $(0.000224)$ & $(0.000272)$ & $(0.000225)$ \\
\hline \multirow[t]{2}{*}{ University degree } & $-0.197^{\star}$ & $-0.395^{\star \star \star}$ & $-0.208^{\star}$ & $-0.381^{\star \star \star}$ & $-0.200^{\star}$ & $-0.350^{\star \star \star}$ & -0.185 & $-0.326^{\star \star \star}$ \\
\hline & $(0.115)$ & $(0.0844)$ & $(0.115)$ & (0.0848) & $(0.115)$ & (0.0853) & $(0.115)$ & $(0.0858)$ \\
\hline \multirow[t]{2}{*}{ Marriage } & 0.0309 & -0.110 & 0.0237 & -0.0892 & 0.0268 & -0.0810 & 0.0746 & 0.00650 \\
\hline & $(0.174)$ & $(0.151)$ & $(0.176)$ & $(0.150)$ & $(0.175)$ & $(0.152)$ & $(0.177)$ & $(0.154)$ \\
\hline \multirow[t]{2}{*}{ Divorce } & $0.484^{\star}$ & $0.597^{\star \star \star}$ & $0.467^{\star}$ & $0.612^{\star \star \star}$ & 0.457 & $0.597^{\star \star \star}$ & $0.474^{*}$ & $0.622^{\star \star \star}$ \\
\hline & $(0.280)$ & $(0.220)$ & $(0.280)$ & $(0.219)$ & $(0.280)$ & $(0.220)$ & $(0.280)$ & $(0.221)$ \\
\hline \multirow[t]{2}{*}{ Household member } & 0.0401 & -0.0111 & 0.0359 & -0.0177 & 0.0352 & -0.0200 & 0.0302 & -0.0301 \\
\hline & $(0.0384)$ & $(0.0284)$ & $(0.0383)$ & $(0.0287)$ & $(0.0384)$ & $(0.0287)$ & $(0.0385)$ & (0.0288) \\
\hline \multirow[t]{2}{*}{ Children } & -0.276 & 0.0655 & -0.272 & 0.0566 & -0.263 & 0.0668 & -0.252 & 0.0927 \\
\hline & $(0.175)$ & $(0.151)$ & $(0.176)$ & $(0.151)$ & $(0.177)$ & $(0.151)$ & $(0.178)$ & $(0.153)$ \\
\hline \multirow[t]{2}{*}{ Unemployed } & -0.322 & -0.0793 & -0.308 & -0.00519 & -0.308 & 0.00268 & -0.357 & -0.0933 \\
\hline & $(0.330)$ & $(0.229)$ & $(0.331)$ & $(0.227)$ & $(0.333)$ & $(0.228)$ & $(0.338)$ & $(0.231)$ \\
\hline \multirow[t]{2}{*}{ Log of household income } & -0.116 & $-0.142^{\star \star}$ & -0.116 & $-0.157^{\star \star}$ & -0.114 & $-0.153^{\star \star}$ & -0.0856 & -0.103 \\
\hline & (0.0924) & $(0.0670)$ & $(0.0927)$ & $(0.0675)$ & $(0.0928)$ & $(0.0676)$ & $(0.0935)$ & $(0.0691)$ \\
\hline \multirow[t]{2}{*}{ Log of household assets } & -0.0540 & $-0.114^{\star \star \star}$ & -0.0454 & $-0.0863^{\star \star}$ & -0.0437 & $-0.0790^{\star}$ & -0.0343 & -0.0605 \\
\hline & $(0.0537)$ & $(0.0414)$ & $(0.0542)$ & $(0.0418)$ & $(0.0545)$ & $(0.0419)$ & $(0.0547)$ & $(0.0421)$ \\
\hline \multirow[t]{2}{*}{ Regular exercise } & & & -0.146 & $-0.383^{\star \star \star}$ & -0.142 & $-0.373^{\star \star \star}$ & -0.121 & $-0.331^{\star \star \star}$ \\
\hline & & & $(0.0972)$ & $(0.0755)$ & $(0.0975)$ & $(0.0756)$ & $(0.0979)$ & $(0.0761)$ \\
\hline \multirow[t]{2}{*}{ Current drinker } & & & 0.163 & $0.325^{\star \star \star}$ & $0.166^{\star}$ & $0.324^{\star * \star}$ & $0.170^{\star}$ & $0.330^{\star \star \star}$ \\
\hline & & & $(0.101)$ & $(0.0749)$ & $(0.101)$ & $(0.0751)$ & $(0.101)$ & $(0.0753)$ \\
\hline \multirow[t]{2}{*}{ Frequent gambler } & & & -0.189 & $0.388^{\star \star \star}$ & -0.192 & $0.359^{\star \star \star}$ & -0.199 & $0.346^{\star \star \star}$ \\
\hline & & & $(0.175)$ & $(0.109)$ & $(0.175)$ & $(0.110)$ & $(0.175)$ & $(0.110)$ \\
\hline \multirow[t]{2}{*}{ Myopic view of the future } & & & & & $0.213^{\star}$ & $0.249^{\star \star}$ & 0.202 & $0.227^{\star \star}$ \\
\hline & & & & & $(0.126)$ & $(0.0969)$ & $(0.126)$ & $(0.0974)$ \\
\hline \multirow[t]{2}{*}{ Level of risk preference } & & & & & 0.0764 & $0.727^{\star \star \star}$ & 0.0855 & $0.742^{\star \star \star}$ \\
\hline & & & & & $(0.248)$ & $(0.185)$ & $(0.249)$ & $(0.186)$ \\
\hline \multirow[t]{2}{*}{ Current level of happiness } & & & & & & & $-0.545^{\star \star}$ & $-0.988^{\star \star \star}$ \\
\hline & & & & & & & $(0.271)$ & $(0.203)$ \\
\hline \multirow[t]{2}{*}{ Anxiety about health } & & & & & & & -0.00764 & -0.00506 \\
\hline & & & & & & & $(0.0955)$ & $(0.0722)$ \\
\hline Constant & 0.683 & 0.181 & 0.617 & 0.264 & 0.481 & -0.456 & 0.325 & -0.735 \\
\hline & $(1.370)$ & $(1.057)$ & $(1.373)$ & (1.065) & $(1.383)$ & $(1.077)$ & $(1.381)$ & $(1.081)$ \\
\hline Observations & 3,706 & 3,706 & 3,706 & 3,706 & 3,706 & 3,706 & 3,706 & 3,706 \\
\hline Log likelihood & -2430 & -2430 & -2400 & -2400 & -2388 & -2388 & -2376 & -2376 \\
\hline Chi2 statistics & 495.7 & 495.7 & 542.8 & 542.8 & 560.3 & 560.3 & 568.4 & 568.4 \\
\hline$p$-value & 0 & 0 & 0 & 0 & 0 & 0 & 0 & 0 \\
\hline
\end{tabular}

Robust standard errors in parentheses, ${ }^{\star \star *} p<0.01,{ }^{* \star} p<0.05,{ }^{*} p<0.1$. 
to make more rational decisions, are less likely to smoke. Using data from the PPS 2010, the probit regression results show that both financial literacy and financial education have a significantly negative impact on smoking behavior. In other words, a high level of financial literacy (which emphasizes knowledge of investments) and receiving financial education (which emphasizes savings behavior) significantly reduces the probability of being a current smoker. These inverse relationships indicate that rational decision-making ability reduces the tendency to engage in irrational behavior. In addition, we find that gender, age, education, marital status, household income and assets, risky behaviors, myopic view of the future, risk preference, and level of happiness also significantly predict the likelihood of a person being a current smoker.

Our findings suggest that promoting financial literacy and financial education could help mitigate smoking behavior. In the case of Japan, the government can integrate financial knowledge that focuses on the investment perspective into the current financial education program to enhance the impact of financial education and financial literacy as countermeasures to smoking. However, further research is needed to explore the impact of financial literacy and financial education as rational decision-making tools in terms of smoking and other health-related behaviors in different contexts.

However, this study has several limitations. First, we base our measurement of financial literacy on only three questions designed by Lusardi and Mitchell $(63,70)$. However, other studies also use this method, which makes financial literacy internationally comparable [e.g., (48, 59, 64-69, 71, 104, 105)]. Second, we define smoking behavior only in terms of participation in smoking, but not the amount of cigarette consumption or the level of tobacco dependence because of data unavailability. Despite these limitations, this study provides empirical evidence that suggests a means to enhance the rational decision-making ability of individuals through financial literacy and financial education to curtail smoking behavior.

\section{REFERENCES}

1. Ministry of Health, Labour and Welfare (MHLW) (2012). A basic direction for comprehensive implementation of national health promotion. Available online at: https://www.mhlw.go.jp/file/06Seisakujouhou-10900000-Kenkoukyoku/0000047330.pdf (accessed July 31,2020 ).

2. Ministry of Health, Labour and Welfare (MHLW). (2019). Outline of the Act on the Partial Revision of the Health Promotion Act, (No. 78 of 2018). Available online at: https://www.mhlw.go.jp/english/policy/health-medical/ health/dl/201904kenko.pdf (accessed July 31, 2020).

3. World Health Organization (WHO). 2015. WHO report on the global tobacco epidemic: raising taxes on tobacco, World Health Organization. Available online at: https://www.who.int/tobacco/global_report/2015/en/ (accessed August 8, 2020).

4. World Health Organization (WHO). 2017. WHO report on the global tobacco epidemic, 2017: Monitoring tobacco use and prevention policies,

\section{DATA AVAILABILITY STATEMENT}

The original contributions presented in the study are included in the article/Supplementary Material, further inquiries can be directed to the corresponding author/s.

\section{ETHICS STATEMENT}

The studies involving human participants were reviewed and approved by Osaka University. The patients/participants provided their written informed consent to participate in this study.

\section{AUTHOR CONTRIBUTIONS}

YK: study design. SW, MK, and YK: analysis and interpretation of data. SW, PP, SO, and MK: writing of the report. All authors contributed to the article and approved the submitted version.

\section{FUNDING}

This work was supported by JPPS KAKENHI Grant Nos. 19K13739 (YK); 19K13684 (MK), and RISTEX, JST (YK).

\section{ACKNOWLEDGMENTS}

This research used micro data from the Preference Parameters Study of Osaka University's twenty-first Century COE Program Behavioral Macrodynamics Based on Surveys and Experiments and its Global COE project Human Behavior and Socioeconomic Dynamics. The authors acknowledge the program/project's contributions of Yoshiro Tsutsui, Fumio Ohtake, and Shinsuke Ikeda.

\section{SUPPLEMENTARY MATERIAL}

The Supplementary Material for this article can be found online at: https://www.frontiersin.org/articles/10.3389/fpubh. 2020.612976/full\#supplementary-material

World Health Organization. Available online at: https://www.who.int/ tobacco/global_report/2017/en/ (accessed August 8, 2020).

5. World Health Organization (WHO). 2019. WHO report on the global epidemic 2019: Offer help to quit tobacco use, World Health Organization. Available online at: https://www.who.int/publications/i/item/who-reporton-the-global-tobacco-epidemic-2019-offer-help-to-quit- tobacco-use (accessed August 8, 2020).

6. GBD 2015 Tobacco Collaborators. Smoking prevalence and attributable disease burden in 195 countries and territories, 1990-2015: a systematic analysis from the global burden of disease study 2015. Lancet. (2017) 389:1885-906. doi: 10.1016/S0140-6736(17)30819-X

7. Farrell M, Howes S, Bebbington P, Brugha T, Jenkins R, Lewis G, et al. Nicotine, alcohol and drug dependence, and psychiatric comorbidity results of a national household survey. Int Rev Psychiatry. (2003) 15:506. doi: 10.1080/0954026021000045949

8. Lawrence D, Mitrou F, Zubrick SR. Smoking and mental illness: results from population surveys in Australia and the United States. 
BMC Public Health. (2009) 9:1-14. doi: 10.1186/1471-24589-285

9. U.S. Department of Health and Human Services (USDHHS). The health consequences of smoking: a report of the Surgeon General. Natl Libr Med. (2004).

10. Midya V, Pal S, Sinharoy A, Das JK, Rao H, Abu-Hasan M, et al. The association between female smoking and childhood asthma prevalence-a study based on aggregative data. Front Public Health. (2018) 6:295. doi: 10.3389/fpubh.2018.00295

11. Ibrahim BA, Al-Humaish S, Al-Obaide MAI. Tobacco smoking, lung cancer, and therapy in Iraq: current perspective. Front Public Health. (2018) 6:311. doi: 10.3389/fpubh.2018.00311

12. Grine G, Royer A, Terrer E, Diallo OO, Drancourt M, Aboudharam G. Tobacco smoking affects the salivary gram-positive bacterial population. Front Public Health. (2019) 7:196. doi: 10.3389/fpubh.2019.00196

13. Wen $\mathrm{H}$, Xie C, Wang F, Wu Y, Yu C. Trends in disease burden attributable to Tobacco in China, 1990-2017: Findings from the global burden of disease study 2017. Front Public Health. (2020) 8:237. doi: 10.3389/fpubh.2020.00237

14. Bush R, Wooden M. Smoking and absence from work: Australian evidence. Soc Sci Med. (1995) 41:437-46. doi: 10.1016/0277-9536(94)00350-3

15. Champion KE, Mather M, Spring B, Kay-Lambkin F, Teesson M, Newton NC. Clustering of multiple risk behaviors among a sample of 18 -year-old Australians and associations with mental health outcomes: a latent class analysis. Front Public Health. (2016) 6:135. doi: 10.3389/fpubh.2018.00135

16. Hori A, Inoue Y, Kuwahara K, Kunugita N, Akter S, Nishiura C, et al. Smoking and long-term sick leave in a Japanese working population: findings of the Japan epidemiology collaboration on occupational health study. Nicotine Tob. Res. (2019). doi: 10.1093/ntr/ntz204. [Epub ahead of print].

17. Ekpu VU, Brown AK. The economic impact of smoking and of reducing smoking prevalence: review of evidence. Tob Use Insights. (2015) 8:TUI.S15628. doi: 10.4137/TUI.S15628

18. Hajat A, Kaufman JS, Rose KM, Siddiqi A, Thomas JC. Do the wealthy have a health advantage? Cardiovascular disease risk factors and wealth. Soc Sci Med. (2010) 71:1935-42. doi: 10.1016/j.socscimed.2010.09.027

19. Cawley J. Reefer madness, frank the tank or pretty woman: to what extent do addictive behaviors respond to incentives? In: Sloan FA, Kasper H, editors. Incentives and Choice in Health Care. Cambridge, MA: MIT Press (2008). p. 163-93. doi: 10.7551/mitpress/9780262195775.003.0007

20. Sloan FA, Wang Y. Economic theory and evidence on smoking behavior of adults. Addiction. (2008) 103:1777-85. doi: $10.1111 / j .1360-0443.2008 .02329 . x$

21. Baker F, Johnson MW, Bickel WK. Delay discounting in current and never-before cigarette smokers: similarities and differences across commodity, sign, and magnitude. J Abnorm Psychol. (2003) 112:38292. doi: 10.1037/0021-843X.112.3.382

22. Barlow P, McKee M, Reeves A, Galea G, Stuckler D. Time-discounting and tobacco smoking: a systematic review and network analysis. Int J Epidemiol. (2017) 46:860-9. doi: 10.1093/ije/dyx060

23. MacKillop J, Amlung MT, Few LR, Ray LA, Sweet LH, Munafò MR. Delayed reward discounting and addictive behavior: a meta-analysis. Psychopharmacology. (2011) 216:305-21. doi: 10.1007/s00213-011-2229-0

24. Ida $T$, Goto R. Simultaneous measurement of time and risk preferences: stated preference discrete choice modeling analysis depending on smoking behavior. Int Econ Rev. (2009) 50:1169-82. doi: 10.1111/j.1468-2354.2009.00564.x

25. Mitchell SH. Measures of impulsivity in cigarette smokers and non-smokers. Psychopharmacology. (1999) 146:455-64. doi: 10.1007/PL00005491

26. O'Donoghue T, Rabin M. Doing it now or later. Am Econ Rev. (1999) 89:103-24. doi: 10.1257/aer.89.1.103

27. Gruber J, Köszegi B. Is addiction rational: theory and evidence. Q J Econ. (2001) 116:1261-304. doi: 10.1162/003355301753265570

28. Rambaud SC, Torrecillas MJM, Takahashi T. Observed and normative discount functions in addiction and other diseases. Front. Pharmacol. (2017) 8:416. doi: 10.3389/fphar.2017.00416

29. Read D, Roelofsma PHMP. Subadditive versus hyperbolic discounting: a comparison of choice and matching. Organ Behav Hum Decis Process. (2003) 91:140-53. doi: 10.1016/S0749-5978(03)00060-8
30. Read D. Is time-discounting hyperbolic or subadditive? J Risk Uncertain. (2001) 23:5-32. doi: 10.1023/A:1011198414683

31. Orphanides A, Zervos D. Rational addiction with learning and regret. J Polit Econ. (1995) 103:739-58. doi: 10.1086/262001

32. Wang $\mathrm{R}$. The optimal consumption and the quitting of harmful addictive goods. B E J Econ Anal Policy. (2007) 7:1-38. doi: 10.2202/1935-1682.1684

33. Ambrose BK, Rostron BL, Johnson SE, Portnoy DB, Apelberg BJ, Kaufman AR et al. Perceptions of the relative harm of cigarettes and e-cigarettes among U.S. youth. Am J Prev Med. (2014) 47:S53-60. doi: 10.1016/j.amepre.2014.04.016

34. Lee YO, Hebert CJ, Nonnemaker JM, Kim AE. Youth tobacco product use in the United States. Pediatrics. (2015) 135:409-15. doi: 10.1542/peds.2014-3202

35. Drovandi A, Teague P-A, Glass B, Malau-Aduli B. Australian school student perceptions of effective anti-tobacco health warnings. Front Public Health. (2018) 6:297. doi: 10.3389/fpubh.2018.00297

36. Grossman M. The human capital model of the demand for health. NBER working paper No. 7078. National Bureau of Economic Research. (1999). doi: 10.3386/w7078

37. World Health Organization (WHO). (2011). Economics of tobacco toolkit: assessment of the economic costs of smoking, World Health Organization. Available online at: https://apps.who.int/iris/handle/10665/44596 (accessed August 8, 2020).

38. Loewenstein GFA. Visceral account of addiction. In: Elster J, Skog OJ, editors. Getting Hooked: Rationality and Addiction. New York, NY: Cambridge University Press (1999). p. 235-64. doi: 10.1017/CBO97811391732 23.010

39. Perikleous EP, Paschalis S, Emmanouil, P, Theodoros CC, Evangelia N. E-Cigarette use among adolescents: an overview of the literature and future perspectives. Front Public Health. (2018) 6:86. doi: 10.3389/fpubh.2018.00086

40. Braunstein S, Welch C, Financial literacy: an overview of practice, research, and policy. Fed Res Bull. (2002) 88:445. doi: 10.17016/bulletin.200 2.88-11

41. Lusardi A, Michaud P-C, Mitchell OS. Optimal financial literacy and saving for retirement. (2011) RAND Working Paper Series No. WR-905-SSA. doi: 10.2139/ssrn. 1978960

42. Yoshino N, Morgan PJ, Trinh LQ. Financial literacy in Japan: determinants and impacts, ADBI Working Paper 796 (2014).

43. Hastings J, Mitchell OS. How financial literacy and impatience shape retirement wealth and investment behaviors. J Pension Econ Financ. (2020) 19:1-20. doi: 10.1017/S1474747218000227

44. Meier S, Sprenger C. Present-biased preferences and credit card borrowing. Am Econ J Appl Econ. (2010) 2:193-210. doi: 10.1257/app.2.1.193

45. Alessie R, Van Rooij M, Lusardi A. Financial literacy and retirement preparation in the Netherlands. J Pension Econ Financ. (2011) 10:527-45. doi: $10.1017 / S 1474747211000461$

46. Boisclair D, Lusardi A, Michaud PC. Financial literacy and retirement planning in Canada. J Pension Econ Financ. (2017) 16:277-96. doi: $10.1017 /$ S1474747215000311

47. Khan MSR, Rabbani N, Kadoya Y. Is financial literacy associated with investment in financial markets in the United States? Sustainability. (2020) 12:1-14. doi: 10.3390/su12187370

48. Lusardi A, Mitchell OS. The economic importance of financial literacy: theory and evidence. J Econ Lit. (2014) 52:5-44. doi: 10.1257/jel. 52.1.5

49. Mandell L. Financial literacy of high school students. In: Xiao JJ, editor. Handbook of Consumer Finance Research. New York, NY: Springer (2008). p. 163-83. doi: 10.1007/978-0-387-75734-6_10

50. Willis LE. The financial education fallacy. Am Econ Rev. (2011) 101:42934. doi: 10.1257/aer.101.3.429

51. Benjamin DJ, Brown SA, Shapiro JM. Who is "behavioral"? Cognitive ability and anomalous preferences. J Eur Econ Assoc. (2013) 11:123155. doi: 10.1111/jeea.12055

52. Gill D, Prowse V. Cognitive ability, character skills, and learning to play equilibrium: a level-k analysis. J Polit Econ. (2016) 124:161976. doi: $10.1086 / 688849$ 
53. James BD, Boyle PA, Bennett JS, Bennett DA. The impact of health and financial literacy on decision making in community-based older adults. Gerontology. (2012) 58:531-9. doi: 10.1159/000339094

54. Bennett JS, Boyle PA, James BD, Bennett DA, Correlates of health and financial literacy in older adults without dementia. BMC Geriatr. (2012) 12:30. doi: 10.1186/1471-2318-12-30

55. Bernheim BD, Garrett DM, Maki DM. Education and saving: the long-term effects of high school financial curriculum mandates. J Public Econ. (2001) 80:435-465. doi: 10.1016/S0047-2727(00)00120-1

56. Brown M, Grigsby J, Van Der Klaauw W, Wen J, Zafar B. Financial education and the debt behavior of the young. Rev Financ Stud. (2016) 29:2490522. doi: 10.1093/rfs/hhw006

57. Bruhn M, Leão L de S, Legovini A, Marchetti R, Zia B. The impact of high school financial education: evidence from a large-scale evaluation in Brazil. Am Econ J Appl Econ. (2016) 8:256-95. doi: 10.1257/app.20150149

58. Kaiser T, Menkhoff L. Does financial education impact financial literacy and financial behavior, and if so, when? World Bank Economic Review. (2017) 31:611-30. doi: 10.1596/1813-9450-8161

59. Watanapongvanich S, Binnagan P, Putthinun P, Khan MSR, Kadoya Y. Financial literacy and gambling behavior: evidence from Japan. J Gambl Stud. (2020). doi: 10.1007/s10899-020-09936-3. [Epub ahead of print].

60. Frederick S, Loewenstein G, O’Donoghue T. Time discounting and time preference: a critical review. Time Decis Econ Psychol Perspect Intertemporal Choice. (2003) 40:13-86. doi: 10.1257/002205102320161311

61. Hurla R, Kim M, Singer E, Soman D. Applying Findings From Financial Literacy to Encourage Responsible Gambling. Toronto, ON: Gambling Research Exchange Ontario (GREO). (2017).

62. Kang M Il, Ikeda S. Time discounting and smoking behavior: evidence from a panel survey. Behav Econ Prefer Choices Happiness. (2016) 23:197226. doi: 10.1007/978-4-431-55402-8_9

63. Lusardi A, Mitchell OS. Planning and financial literacy: how do women fare? Am Econ Rev. (2008) 98:413-7. doi: 10.1257/aer.98.2.413

64. Fornero E, Monticone C. Financial literacy and pension plan participation in Italy. J Pension Econ Financ. (2011) 10:54764. doi: 10.1017/S1474747211000473

65. Kadoya Y, Khan MSR. Can financial literacy reduce anxiety about life in old age? J Risk Res. (2018) 21:1533-50. doi: 10.1080/13669877.2017.1313760

66. Kadoya Y, Khan MSR. What determines financial literacy in Japan? J Pension Econ Financ. (2020) 19:353-71. doi: 10.1017/S1474747218000379

67. Kadoya Y, Khan MSR, Hamada T, Dominguez A. Financial literacy and anxiety about life in old age: evidence from the USA. Rev Econ Househ. (2018) 16:859-78. doi: 10.1007/s11150-017-9401-1

68. Kadoya Y, Khan MSR, Oba H, Narumoto J. Factors affecting knowledge about the adult guardianship and civil trust systems: evidence from Japan. J Women Aging. (2020). doi: 10.1080/08952841.2020.1727711. [Epub ahead of print].

69. Klapper L, Panos GA. Financial literacy and retirement planning: the Russian case. J Pension Econ Financ. (2011) 10:599-618. doi: 10.1017/S1474747211000503

70. Lusardi A, Mitchell OS. Financial literacy around the world: an overview. J Pension Econ Financ. (2011) 10:497-508. doi: 10.1017/S1474747211000448

71. Sekita S. Financial literacy and retirement planning in Japan. J Pension Econ Financ. (2011) 10:637-56. doi: 10.1017/S1474747211000527

72. Messy F-A, Monticone C. Financial Education Policies in Asia and the Pacific. OECD Working Paper. Financ Insur Priv Pensions. (2016) 40:66. doi: $10.1787 / 5 \mathrm{jm} 5 \mathrm{~b} 32 \mathrm{v} 5 \mathrm{vvc}-\mathrm{en}$

73. Aekplakorn W, Hogan MC, Tiptaradol S, Wibulpolprasert S, Punyaratabandhu P, Lim SS. Tobacco and hazardous or harmful alcohol use in Thailand: joint prevalence and associations with socioeconomic factors. Addict Behav. (2008) 33:503-14. doi: 10.1016/j.addbeh.2007.10.010

74. Audrain-McGovern J, Rodriguez D, Moss HB, Smoking progression and physical activity. Cancer Epidemiol Biomarkers Prev. (2003) 12:1121-9.

75. Bauer T, Göhlmann S, Sinning M. Gender differences in smoking behavior. Health Econ. (2007) 16:895-909. doi: 10.1002/hec.1259

76. Giovino GA, Mirza SA, Samet JM, Gupta PC, Jarvis MJ, Bhala N, et al. Tobacco use in 3 billion individuals from 16 countries: an analysis of nationally representative cross-sectional household surveys. Lancet. (2012) 380:668-79. doi: 10.1016/S0140-6736(12)61085-X
77. Lahelma E, Pietiläinen O, Ferrie J, Kivimäki M, Lahti J, Marmot M, et al. Changes over time in absolute and relative socioeconomic differences in smoking: a comparison of cohort studies from Britain, Finland, and Japan. Nicotine Tob Res. (2016) 18:1697-704. doi: 10.1093/ntr/ntw004

78. Witvorapong N, Vichitkunakorn P. Investigation of tobacco and alcohol coconsumption in Thailand: a joint estimation approach. Drug Alcohol Rev. (2020). doi: 10.1111/dar.13128. [Epub ahead of print].

79. Fukuda Y, Nakamura K, Takano T. Socioeconomic pattern of smoking in Japan: income inequality and gender and age differences. Ann Epidemiol. (2005) 15:365-72. doi: 10.1016/j.annepidem.2004.09.003

80. Meijer E, Gebhardt WA, Van Laar C, Kawous R, Beijk SCAM. Socioeconomic status in relation to smoking: the role of (expected and desired) social support and quitter identity. Soc Sci Med. (2016) 162:419. doi: 10.1016/j.socscimed.2016.06.022

81. Pennanen M, Broms U, Korhonen T, Haukkala A, Partonen T, TuulioHenriksson A, et al. Smoking, nicotine dependence and nicotine intake by socio-economic status and marital status. Addict Behav. (2014) 39:114551. doi: 10.1016/j.addbeh.2014.03.005

82. Reid JL, Hammond D, Boudreau C, Fong GT, Siahpush M. Socioeconomic disparities in quit intentions, quit attempts, and smoking abstinence among smokers in four western countries: findings from the International Tobacco Control Four Country Survey. Nicotine Tob Res. (2010) 12:S2033. doi: 10.1093/ntr/ntq051

83. Schaap MM, Kunst AE. Monitoring of socio-economic inequalities in smoking: learning from the experiences of recent scientific studies. Public Health. (2009) 123:103-9. doi: 10.1016/j.puhe.2008. 10.015

84. Vedøy TF. Tracing the cigarette epidemic: an age-period-cohort study of education, gender and smoking using a pseudo-panel approach. Soc Sci Res. (2014) 48:35-47. doi: 10.1016/j.ssresearch.2014. 05.005

85. Wetter DW, Cofta-Gunn L, Irvin JE, Fouladi RT, Wright K, Daza P, et al. What accounts for the association of education and smoking cessation? Prev Med. (2005) 40:452-60. doi: 10.1016/j.ypmed.2004.07.001

86. Zhu BP, Giovino GA, Mowery PD, Eriksen MP. The relationship between cigarette smoking and education revisited: implications for categorizing persons' educational status. Am J Public Health. (1996) 86:15829. doi: 10.2105/AJPH.86.11.1582

87. Lindström M. Social capital, economic conditions, marital status and daily smoking: a population-based study. Public Health. (2010) 124:717. doi: 10.1016/j.puhe.2010.01.003

88. Castrén S, Kontto J, Alho H, Salonen AH. The relationship between gambling expenditure, socio-demographics, health-related correlates, and gambling behaviour-a cross-sectional population-based survey in Finland. Addiction. (2018) 113:91-106. doi: 10.1111/add.13929

89. Charilaou M, Karekla M, Constantinou M, Price S. Relationship between physical activity and type of smoking behavior among adolescents and young adults in Cyprus. Nicotine Tob Res. (2009) 11:969-76. doi: 10.1093/ntr/ntp096

90. Chasandra M, Goudas M, Theodorakis Y. Exercise and smoking: a literature overview. Health (Irvine. Calif). (2015) 07:1477-91. doi: 10.4236/health.2015.711162

91. Leatherdale ST, Wong SL, Manske SR, Colditz GA. Susceptibility to smoking and its association with physical activity, BMI, and weight concerns among youth. Nicotine Tob Res. (2008) 10:499-505. doi: 10.1080/14622200801902201

92. Nichter M, Nichter M, Carkoglu A, Lloyd-Richardson E. Smoking and drinking among college students: "It's a package deal." Drug Alcohol Depend. (2010) 106:16-20. doi: 10.1016/j.drugalcdep.2009.07.025

93. Bobo JK, Husten C. Sociocultural influences on smoking and drinking. Alcohol Res Heal. (2000) 24:225-32.

94. Weitzman ER, Chen YY. The co-occurrence of smoking and drinking among young adults in college: National survey results from the United States. Drug Alcohol Depend. (2005) 80:377-86. doi: 10.1016/j.drugalcdep.2005. 05.008

95. Bussu A, Detotto C. The bidirectional relationship between gambling and addictive substances. Int Gambl Stud. (2015) 15:285-308. doi: 10.1080/14459795.2015.1042493 
96. Lorains FK, Cowlishaw S, Thomas SA. Prevalence of comorbid disorders in problem and pathological gambling: systematic review and meta-analysis of population surveys. Addiction. (2011) 106:490-8. doi: 10.1111/j.1360-0443.2010.03300.x

97. Petry NM, Stinson FS, Grant BF. Comorbidity of DSM-IV pathological gambling and other psychiatric disorders: results from the national epidemiologic survey on alcohol and related conditions. J Clin Psychiatry. (2005) 66:564-74. doi: 10.4088/JCP.v66n0504

98. Odum AL, Madden GJ, Bickel WK. Discounting of delayed health gains and losses by current, never- and ex-smokers of cigarettes. Nicotine Tob Res. (2002) 4:295-303. doi: 10.1080/146222002101 41257

99. Anderson LR, Mellor JM, Predicting health behaviors with an experimental measure of risk preference. J Health Econ. (2008) 27:1260-74. doi: 10.1016/j.jhealeco.2008.05.011

100. Pfeifer C. A note on smoking behavior and health risk taking. Nord J Heal Econ. (2012) 1:135-51. doi: 10.5617/njhe.195

101. Chang T, Chu HP, Deale FW, Gupta R. The causal relationship between happiness and smoking: a bootstrap panel causality test. J Happiness Stud. (2016) 17:1327-36. doi: 10.1007/s10902-015-9645-5

102. Kassel JD, Stroud LR, Paronis CA. Smoking, stress, and negative affect: correlation, causation, and context across stages of smoking.
Psychol Bull. (2003) 129:270-304. doi: 10.1037/0033-2909.129. 2.270

103. Weinhold D, Chaloupka FJ. Smoking status and subjective well-being. Tob Control. (2017) 26:195-201. doi: 10.1136/tobaccocontrol-2015-052601

104. Almenberg J, Säve-Söderbergh J, Financial literacy and retirement planning in Sweden. J Pension Econ Financ. (2011) 10:58598. doi: 10.1017/S1474747211000497

105. Crossan D, Feslier D, Hurnard R. Financial literacy and retirement planning in New Zealand. J Pension Econ Financ. (2011) 10:61935. doi: 10.1017/S1474747211000515

Conflict of Interest: The authors declare that the research was conducted in the absence of any commercial or financial relationships that could be construed as a potential conflict of interest.

Copyright (c) 2021 Watanapongvanich, Khan, Putthinun, Ono and Kadoya. This is an open-access article distributed under the terms of the Creative Commons Attribution License (CC BY). The use, distribution or reproduction in other forums is permitted, provided the original author(s) and the copyright owner(s) are credited and that the original publication in this journal is cited, in accordance with accepted academic practice. No use, distribution or reproduction is permitted which does not comply with these terms. 